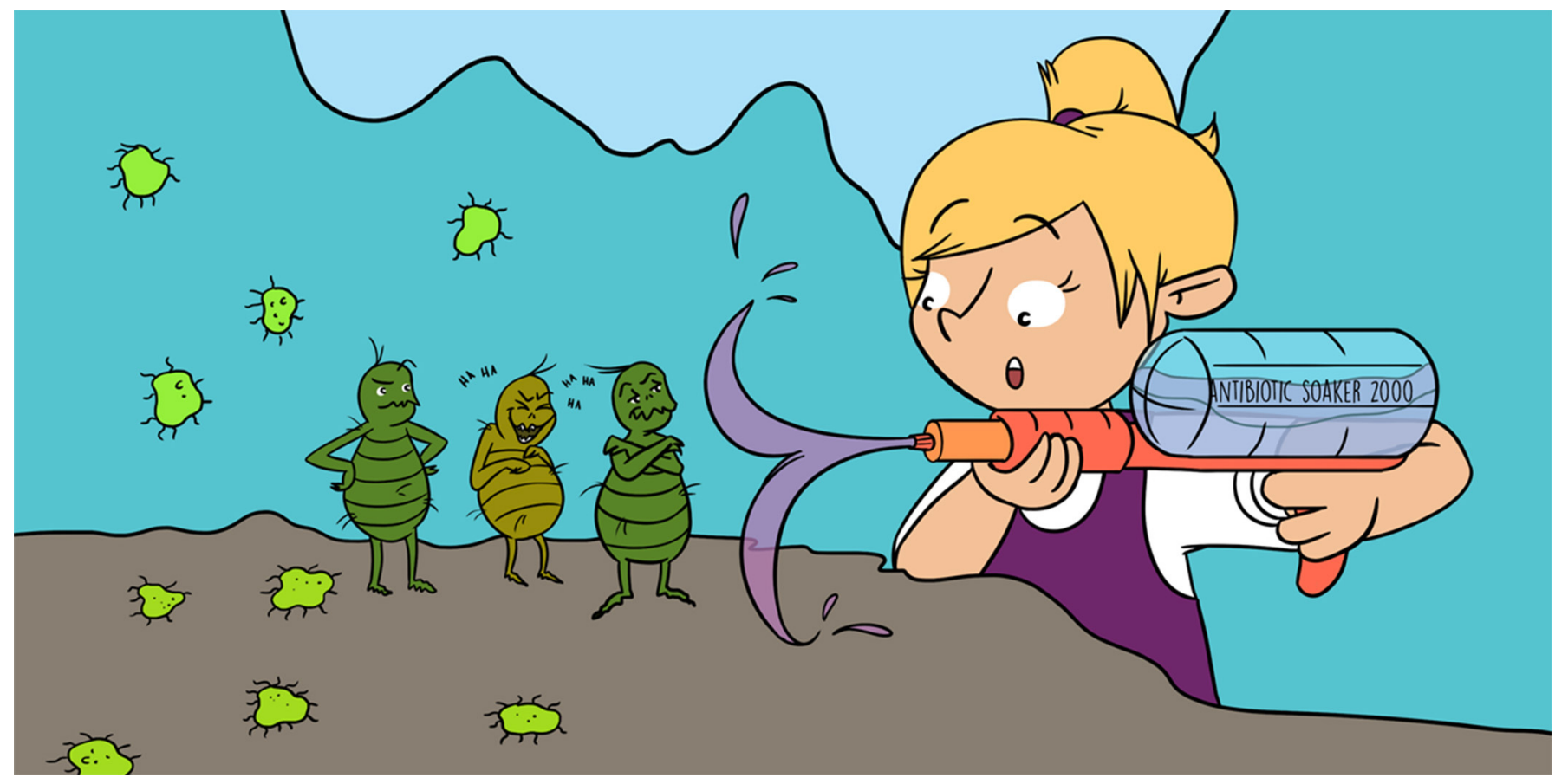

\title{
SUPERBUGS AMONG US: WHO THEY ARE AND WHAT CAN YOU DO TO HELP WIN THE FIGHT?
}

\section{Maria Letícia Bonatelli ${ }^{1}$, Laura Maria Andrade Oliveira ${ }^{2}$ and Tatiana Castro Abreu Pinto ${ }^{2 *}$}

${ }^{1}$ Escola Superior de Agricultura Luiz de Queiroz, Universidade de São Paulo, Sáo Paulo, Brazil

${ }^{2}$ Instituto de Microbiologia Paulo de Goes, Universidade Federal do Rio de Janeiro, Rio de Janeiro, Brazil

YOUNG REVIEWER:

FELIX

AGE: 16
Antibiotics are essential medicines used to treat diseases caused by bacteria. Bacteria are tiny organisms (microbes or "bugs") that can be found in our bodies, in animals, and in the environment. Most bacteria are helpful, so antibiotics are used to kill only some bacteria-those that can cause disease. However, since the discovery of the first antibiotic, disease-causing bacteria have been finding ways to survive, acquiring resistance to antibiotics and even turning into superbugs. Superbugs are one of the most important threats to human health today, so they should be prevented and controlled. In this article, we will tell you about the history of antibiotics, the rise of superbugs, and what you can do to join the fight against superbugs. 


\section{SUPERBUGS}

Bacteria that have many weapons to fight against antibiotics and are therefore resistant to them.

\section{MICROBES}

Tiny living organisms that can only be seen with a microscope and can be found in us, animals, and the environment.

\section{BACTERIA}

One type of microbes. Bacteria with antibiotic resistance have become dangerous superbugs.

\section{ANTIBIOTICS}

Medicines used to treat diseases caused by bacteria.

\section{SUPERBUGS? BUT I DO NOT EVEN KNOW WHAT A REGULAR "BUG" IS...}

In order to understand what superbugs are, we need to first understand what a regular microbe, or "bug," is. Microbes are tiny organisms that can only be seen with a microscope and can be found almost everywhere. Bacteria, viruses, fungi, and protozoa are different types of microbes. If you look around your house, the plants, animals, food, and even you are full of them. But do not panic! Most microbes actually help us. For example, some microbes that live in our intestines have an essential role in helping us digest the food we eat. Other microbes that live in the environment are essential for manufacturing certain kinds of foods. Cheese and yogurt, for example, are formed when microbes grow in milk $[1,2]$.

However, there are also bad microbes in the world. These can make us sick and even put our lives at risk. If you investigate the history of human civilizations, there were many diseases caused by different microbes that led to the death of millions of people. Some remarkable examples are the Spanish Flu (caused by a virus) in the early twentieth century and the Black Death (caused by a bacterium) in the mid-fourteenth century. It is estimated that, together, these two diseases killed around 300 million people [3].

Because they can potentially kill so many people, we need to figure out ways to control the spread of these bad microbes. The most effective way to do that depends on the type of microbe causing the disease. In this article, we focus on bacteria, and one of the most efficient ways to treat diseases caused by bacteria is by using medicines called antibiotics. Breaking down the word antibiotic can help us understand its meaning: anti-meaning opposed to or against; and biotic-meaning related to life or living things. In this case, the living thing refers to bacteria, since antibiotics are usually ineffective against other types of microbes (viruses, fungi, or protozoa). But do you know how antibiotics were first discovered?

\section{THE DISCOVERY OF PENICILLIN AND THE ANTIBIOTIC REVOLUTION}

Alexander Fleming was a British physician/scientist who became interested in studying bacteria after he returned from World War I, where he witnessed several soldiers dying from bacterial infections. After the war, he became a Professor of Bacteriology (the science that studies bacteria) at St. Mary's Hospital in London, United Kingdom. He studied a bacterium named Staphylococcus, which can cause a variety of infections. To study Staphylococcus, Fleming needed to grow them in the laboratory. He used a plate (a circular, flat dish made of glass or plastic) filled with a nutritional medium that enables the growth of microbes [4]. 
Figure 1

Representation of the culture plates observed by Alexander Fleming that helped him to discover the first antibiotic, penicillin. Penicillin is produced by the fungus

Penicillium.

\section{PENICILLIN}

The first antibiotic to be discovered, in 1928, by Alexander Fleming. The antibiotic was named after the microbe that produces it, a fungus called Penicillium

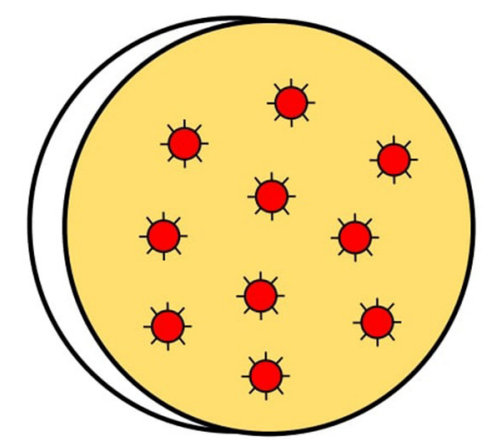

Plate with bacteria Staphylococcus Notice that the bacteria grow well in all of the plate.

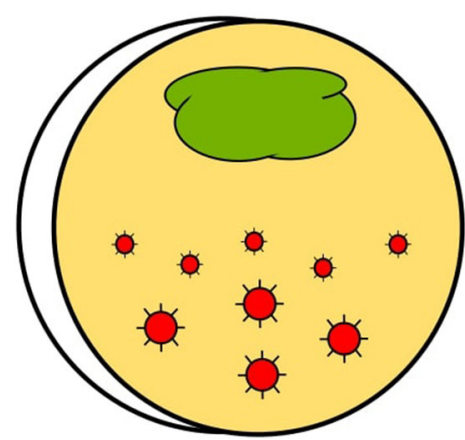

Plate with bacteria Staphylococcus and fungus Penicillium - Notice that the bacteria can not grow around the fungus.

Figure 1

One day in 1928, Fleming noticed another microbe growing on his plates-a fungus called Penicillium. This fungus is harmless to humans and is frequently found in soil and on spoiled food. Fleming observed that where the fungus grew, bacteria did not. Somehow, the fungus was producing something that killed Staphylococcus (see Figure 1). This accidental finding led to the discovery of the first antibiotic, penicillin, which was named after the microbe producing it.

In 1941, penicillin was used for the first time to treat a bacterial infection in a human being. Penicillin became an essential medicine during World War II, helping to prevent many soldiers' deaths. This was the beginning of the "antibiotic revolution." After the discovery of penicillin, scientists found that many other microbes are able to produce other types of antibiotics. Most of these microbes live in the soil and are harmless to humans, and they produce antibiotics to protect themselves against other soil microbes or to compete for space in the environment.

Between 1940 and 1970, several new antibiotics were discovered, and bacterial diseases were easily treated using these medicines. People even thought that a day would come when humans would destroy bad bacteria for good! But it did not happen like that...

\section{THE RISE OF SUPERBUGS}

Bacteria are living organisms. As human beings evolved during the last 3 million years and fought to survive through the changes that happened in the world, bacteria did the same. As antibiotics began to be widely used to treat infections, bacteria started to find ways to survive, by acquiring resistance to antibiotics. 
Figure 2

How bacteria can become resistant to an antibiotic and turn into superbugs. In the presence of the antibiotic, only the bacteria that have the antidote (antibiotic resistance) will survive. Then, those antibiotic-resistant bacteria will reproduce to create more resistant bacteria.

\section{ANTIBIOTIC}

\section{RESISTANCE}

When bacteria are not killed by antibiotics; the weapon used by bacteria to survive antibiotics.
Initially, few bacteria have resistance): blue bacteria.

Only the bacteria that have the antidote will survive.
Soon, the bacteria that survived will multiply and form an adapted bacterial population where everyone has the antidote!

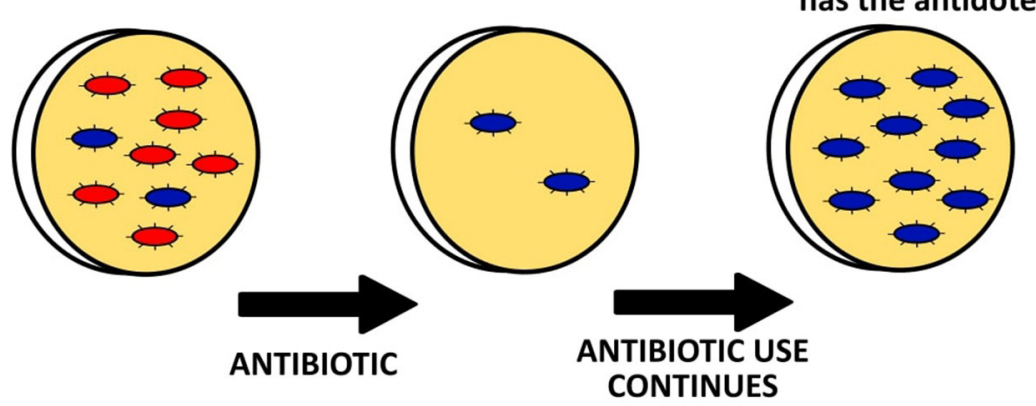

If different antibiotics are indiscriminally used in human and animal health, discarded into the environment, soon several bacteria will suffer the same process described above, acquiring the antidote to different antibiotics, becoming superbugs!

But how can bacteria become resistant to antibiotics? Let us remember that antibiotics are natural products of some microbes. Thus, it makes sense that microbes that naturally produce antibiotics are also naturally resistant to them. This means that resistance to antibiotics is as old as antibiotics themselves and has always existed in nature.

So, when antibiotics are used too much and too frequently and whole populations of bacteria are being exterminated by them, only those bacteria that have the "antidote," called antibiotic resistance, will survive. Some bacteria acquire antibiotic resistance from nature, and those resistant bacteria then survive to start a new generation of bacteria. The new generation will then all be resistant to that particular antibiotic (see Figure 2). That means that this antibiotic will no longer work for treating infections caused by these bacteria. But that would be okay, since we have discovered several different antibiotics, right?

Wrong! Some bacteria can simultaneously have resistance against many antibiotics, turning them into superbugs for which we may not have any antibiotic options soon. Interestingly, one of the first superbugs that spread among humans was Staphylococcus, the very same microbe that led to the discovery of penicillin decades before.

Initially, superbugs were only a threat in hospitals. Because there are so many patients in hospitals, and different types of antibiotics are used to treat different infections, superbugs can easily survive and be transmitted from one person to another in the hospital setting. However, superbugs are everywhere now. They have been found in 
healthy people outside of hospitals, in animals, and in the environment. No matter where they have been found, the appearance of superbugs happened because of the widespread use of antibiotics. In farm animals, for example, antibiotics are administered to prevent and treat infections and to promote faster growth. Superbugs from animals and the environment can be transmitted to humans, either through contact or by eating contaminated food [5-7].

\section{HOW CAN WE BEAT SUPERBUGS AND WHY YOU SHOULD HELP?}

If superbugs are resistant to the antibiotics that are currently available, why do not scientists just discover new antibiotics? Unfortunately, it is not so simple. The process of discovering a new antibiotic in nature, and producing lots of it so it can be used by people, is complex, time-consuming, and very expensive.

So, we are currently facing a challenging and disturbing scenario. People infected with superbugs usually require an expensive treatment, using medicine that is more toxic than antibiotics, and they stay in the hospital a long time. Unfortunately, these people often end up dying. The World Health Organization estimates that, by 2050, infections caused by superbugs will cost approximately USD 84 trillion and will be responsible for nearly 10 million deaths in the world each year, which is a burden greater than cancer [5-7].

Since discovering new antibiotics is a difficult and slow task, the most important action that we can take to control superbugs is to reduce the inappropriate use of antibiotics in order to stop resistant bacteria from spreading. It is well-known today that controlling the spread of superbugs in humans depends on the control of superbugs in animals, food, and the whole environment. This means that everyone should get involved in this fight: medical doctors, veterinary doctors, environmental scientists, food specialists, and you!

One important action that all of us can do is to use antibiotics correctly and only when needed. We should stick to antibiotics that are prescribed by a physician; taking antibiotics without a prescription is highly discouraged. In addition, other simple public health strategies can help controlling superbugs. These include vaccination, access to clean water, basic sanitation, good hygiene, correct food preparation, and appropriate hand washing.

As far as treating people who have been infected by superbugs, scientists have been searching for and evaluating non-antibiotic alternatives, including some very cool and different medicines. These include the use of certain viruses (called bacteriophages) that can kill bacteria. Although promising, many of these alternative therapies are still being researched and are not yet available as real treatment 
options. The path may still be long, but we all should do what we can now if we want to win the fight against superbugs.

\section{REFERENCES}

1. Sassone-Corsi, M., and Raffatellu, M. 2015. No vacancy: how beneficial microbes cooperate with immunity to provide colonization resistance to pathogens. J. Immunol. 194:4081-7. doi: 10.4049/jimmunol.1403169

2. Colombo, M., Todorov, S. D., Eller, M., and Nero, L. A. 2018. The potential use of probiotic and beneficial bacteria in the Brazilian dairy industry. J. Dairy Res. 85:487-96. doi: 10.1017/S0022029918000845

3. Tognotti, E. 2013. Lessons from the history of quarantine, from plague to influenza A. Emerg. Infect. Dis. 19:254-9. doi: 10.3201/eid1902.120312

4. Aldridge, S., Parascandola, J., and Sturchio, J. L. 1999. The Discovery and Development of Penicillin 1928-1945. The Alexander Fleming Laboratory Museum, London, UK, November 19, 1999: An International Historic Chemical Landmark. London: Royal Society of Chemistry and American Chemical Society.

5. Centers for Disease Control and Prevention. 2013. Antibiotic Resistance Threats in the United States. Available online at: https: / / www. cdc.gov/ drugresistance/pdf/ar-threats-2013-508.pdf

6. World Health Organization. 2017. Global Priority List of Antibiotic-Resistant Bacteria to Guide Research, Discovery, and Development of New Antibiotics. Available online at: https://www. who.int/medicines/publications/ WHO-PPL-Short_Summary_25Feb-ET_NM_WHO.pdf?ua=1

7. Van Puyvelde, S., Deborggraeve, S., and Jacobs, J. 2018. Why the antibiotic resistance crisis requires a One Health approach. Lancet Infect. Dis. 18:132-4. doi: 10.1016/S1473-3099(17)30704-1

SUBMITTED: 27 May 2019; ACCEPTED: 20 January 2020; PUBLISHED ONLINE: 11 February 2020.

EDITED BY: Michel Goldman, Institute for Interdisciplinary Innovation in Healthcare (I3H), Belgium

CITATION: Bonatelli ML, Oliveira LMA and Pinto TCA (2020) Superbugs Among Us: Who They Are and What Can You Do to Help Win the Fight? Front. Young Minds 8:5. doi: 10.3389/frym.2020.00005

CONFLICT OF INTEREST: The authors declare that the research was conducted in the absence of any commercial or financial relationships that could be construed as a potential conflict of interest.

COPYRIGHT @ 2020 Bonatelli, Oliveira and Pinto. This is an open-access article distributed under the terms of the Creative Commons Attribution License (CC BY). The use, distribution or reproduction in other forums is permitted, provided the original author(s) and the copyright owner(s) are credited and that the original publication in this journal is cited, in accordance with accepted academic practice. No use, distribution or reproduction is permitted which does not comply with these terms. 


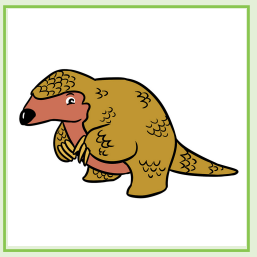

\section{YOUNG REVIEWER}

\section{FELIX, AGE: 16}

I am a high-school student at Ecole Decroly in Brussels. I have a variety of interests and enjoy studying sciences and the humanities. My hobbies include playing rugby, rock climbing, watching documentaries, hanging out with my friends. Also, I enjoy being a member of the Boy Scout movement. I was pleased to contribute to this interesting article.

\section{AUTHORS}
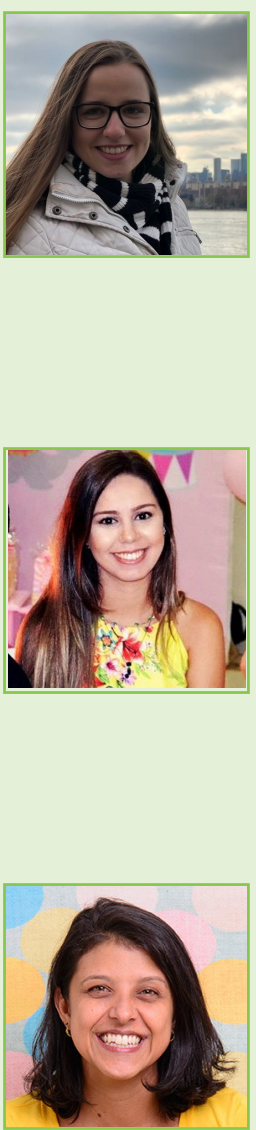

\section{MARIA LETÍCIA BONATELLI}

I am a biologist who is passionate about microbes. During my graduate studies, I focused on studying the microbes that live in industrial environments, and I tried to understand what they were doing there. I was always fascinated by the idea that microbes are everywhere and that they can shape our world. Now, I am a researcher at the University of São Paulo (USP) in Brazil, and I am trying to understand how different bacteria can help us improve crop production, that is, help us grow more and better food to eat.

\section{LAURA MARIA ANDRADE OLIVEIRA}

I am a Pharmacist, M.Sc. in Biological Sciences, with emphasis in Immunology and Infectious Diseases. I studied at the Federal University of Juiz de Fora (UFJF) and got a Ph.D. in Microbiology at the Federal University of Rio de Janeiro (UFRJ), both in Brazil. I am enthusiastic about the microbial world and I am interested in understanding how microbes are connected to our health and how they can cause disease. I believe that sharing the knowledge generated by the academic community with everyone is important for science to keep advancing.

\section{TATIANA CASTRO ABREU PINTO}

I got my Ph.D. in Microbiology from the Federal University of Rio de Janeiro (UFRJ) in Brazil, and have been an Associate Professor at Instituto de Microbiologia Paulo de Goes (IMPPG) of UFRJ since 2014. I coordinate a research group focused on understanding the virulence and antimicrobial-resistant aspects of certain disease-causing bacteria. I am also a mother, wife, daughter, and Brazilian citizen. I have been passionate about science since elementary school and have dedicated the last few years to enhancing the enthusiasm for science among the general population and encouraging and inspiring the next generation of scientists in my country. *tcap@micro.ufrj.br 